\title{
DISEÑO, IMPLEMENTACIÓN Y EVALUACIÓN DE UN PROGRAMA DE COMUNICACIÓN DE RIESGOS COMO ESTRATEGIA DE PREVENCIÓN DE LA INFECCIÓN POR VIH EN ADOLESCENTES
}

\section{Design, implementation and evaluation of a risk communication program as a strategy for the prevention of HIV infection in adolescents}

Mariana Juárez Moreno, Ismael García Cedillo, Leonardo Ernesto Márquez Mireles, Raúl Morales Villegas, Ana Cristina Cubillas Tejeda ${ }^{1}$

Universidad Autónoma de San Luis Potosí. México

\begin{abstract}
Resumen
La infección por el virus de la inmunodeficiencia humana (VIH) es un problema de salud pública mundial. Los adolescentes son un grupo vulnerable frente a la infección por el $\mathrm{VIH}$, por ello se requieren estrategias de prevención acordes a esta población. Por lo anterior el objetivo del estudio fue diseñar, implementar y evaluar un Programa de Comunicación de Riesgos como estrategia de educación para la salud, para la prevención de la infección por VIH en adolescentes. El estudio fue un ensayo de intervención no aleatorizado en tres etapas: 1) diagnóstico previo, 2) diseño e implementación del programa, y 3) evaluación después de la intervención. Se realizó desde junio de 2013 a diciembre de 2015. Fue una investigación mixta, se utilizaron diferentes herramientas de recolección de datos. Participaron 177 estudiantes de zona rural y 254 de zona urbana (15 a 20 años de edad) de San Luis Potosí, México. Los resultados se triangularon para tener una comprensión integral de los conocimientos, percepciones y riesgo de infección de los estudiantes. Después de la intervención se encontró que los adolescentes percibieron riesgos e integraron conocimientos respecto a las vías de transmisión del $\mathrm{VIH}$, conductas de riesgo, y conductas de protección. La comunicación de riesgos puede ser es una estrategia efectiva para la prevención de la infección por VIH. Se recomienda que en su diseño e implementación se considere el contexto sociocultural, se favorezca el aprendizaje significativo y la participación.
\end{abstract}

Palabras clave: Comunicación y salud; adolescentes; comunicación; educación para la salud; percepción; prevención; VIH; sida.

\footnotetext{
${ }^{1}$ Autor de contacto: Ana Cristina Cubillas Tejeda acris@uaslp.mx
} 
Diseño, implementación y evaluación de un programa de comunicación de riesgos como estrategia de prevención de la infección por VIH en adolescentes

\begin{abstract}
Human immunodeficiency virus (HIV) infection is a global public health problem. Adolescents are a vulnerable group against HIV infection, therefore prevention strategies are required according to this population. Therefore, the objective of the study was to design, implement and evaluate a Risk Communication Program as a strategy for health education for the prevention of HIV infection in adolescents. The study was a non-randomized intervention trial in three stages: 1) previous diagnosis, 2) design and implementation of the program, and 3) post-intervention evaluation. It was done from June 2013 to December 2015. It was a mixed research; different data collection tools were used. Participants included 177 students from rural areas and 254 from urban areas (15 to 20 years old) from San Luis Potosí, México. The results were triangulated to have a comprehensive understanding of students' knowledge, perceptions and risk of infection. After the intervention, adolescents perceived risks and integrated knowledge regarding HIV transmission routes, risk behaviours, and protective behaviours. Risk communication can be an effective strategy for the prevention of HIV infection. It is recommended that the socio-cultural context be considered in its design and implementation, meaningful learning and participation should be encouraged.

Keywords: Communication and health; adolescents; communication; education for health; perception; prevention; HIV; aids.

\section{Cómo citar el artículo}

Juárez Moreno, M., García Cedillo, I., Márquez Mireles, L. E., Morales Villegas, R., Cubillas Tejeda, A. C. (2017). Diseño, implementación y evaluación de un programa de comunicación de riesgos como estrategia de prevención de la infección por VIH en adolescentes. Revista de Comunicación y Salud, vol. 7, pp. 81-102. Recuperado de http://revistadecomunicacionysalud.org/index.php/rcys/article/view/125
\end{abstract}

Estudio apoyado por el Fondo Sectorial de Investigación en Salud y Seguridad Social (Proyecto SALUD-142064) y por el Centro Nacional para la prevención y control del VIH y el sida (Proy-2015-102).

Se agradece el apoyo de las autoridades de las escuelas, a los padres de familia y principalmente a los adolescentes participantes.

\title{
1. INTRODUCCIÓN
}

En la actualidad, la infección por el virus de la inmunodeficiencia humana (VIH) y el síndrome de inmunodeficiencia adquirida (sida) son un grave problema de salud (OMS, 2016; Suárez, 2014). A nivel mundial en 2015 se reportaron 36.7 millones de personas infectadas con el VIH y 2.1 millones de nuevos casos, 34\% de éstos se presentó en adolescentes (Joint United Nations Programme on HIVIADIS, 2015). En México, durante 2016 se reportaron 5,145 nuevos casos de infección y 4,112 casos notificados de sida, entre ellos 605 hombres y 101 mujeres tienen entre 15 y 24 años. De los nuevos casos de infección reportados en México en 2016, 5,007 fueron infectados por vía sexual (Secretaría de Salud, 2016). 
Diseño, implementación y evaluación de un programa de comunicación de riesgos como estrategia de prevención de la infección por VIH en adolescentes

La vulnerabilidad frente al VIH es el conjunto de factores económicos, políticos y socioculturales, que coloca a las personas o comunidades, en situaciones que reducen su capacidad para evitar el riesgo de infección (Pavia et al., 2012; Quintal y Vega, 2015). Los adolescentes, por cuestiones fisiológicas, psicológicas y sociales, se encuentran en mayor riesgo de infección por VIH (Shilpa-Khanna et al., 2015). Además, los cambios psicológicos en los adolescentes originan una percepción de invulnerabilidad, por lo que no contemplan modificar las conductas sexuales riesgosas (Pavia et al., 2012). Existen factores que incrementan la vulnerabilidad en los adolescentes, tales como, la falta de educación, de cuidados paternos, de acceso a servicios de salud, y la información errada o nula que algunos tienen sobre el $\mathrm{VIH}$ (UNFPA, 2016; Folch et al., 2015; Shilpa-Khanna et al., 2015).

Para que una estrategia de prevención tenga más posibilidades de éxito, debe enfocarse en modificar conocimientos, actitudes y promover el desarrollo de habilidades que fortalezcan el autocuidado (Quevedo-Gómez et al., 2011; Berrio, 2014); considerando además factores socioeconómicos, ambientales, culturales y psicosociales (OMS, 2016; Conde-Ferráez et al, 2016; Hanass-Hancock, 2014; St. Lawrence et al., 2013; Zambrano et al., 2013). Con base en lo anterior, una estrategia que puede ser útil para la prevención de la infección por el VIH es la Comunicación de Riesgos (CR), la cual es sensible al contexto, a las actitudes y creencias de los participantes. La CR busca persuadir, educar e influir en la población objetivo, sobre aquellos factores y amenazas que ponen en peligro su salud (Moreno-Sánchez et al 2016; March, 2011). Para su desarrollo se han propuesto una serie de pasos (Figura 1) y recomendaciones, los cuales permiten el diseño de estrategias contextualizadas (Cubillas-Tejeda y González Mares, 2015; Moreno-Sánchez et al).

En un programa de CR (PCR) es primordial conocer la percepción, conocimientos y preocupaciones frente al riesgo en la población que será blanco de los mensajes, para que el programa sea acorde al contexto social y se favorezca la participación. La percepción de riesgos es la capacidad que tiene una persona para interpretar una situación potencialmente dañina para la salud o la vida propia o de otros, con base en experiencias previas y en proyecciones futuras; depende del contexto social y cultural (March, 2011; Slovic, 2004). Para el análisis de la población objetivo es recomendable utilizar herramientas de recolección de datos cualitativas y cuantitativas, lo que permitirá la triangulación de la información para darle validez a la misma (Terán-Hernández, Díaz-Barriga y Cubillas-Tejeda, 2016; Cubillas-Tejeda y González Mares, 2015).

El futuro de la infección por VIH, depende en gran parte de los esfuerzos que se realicen para prevenir la infección, principalmente de la gente joven (OMS, 2016; ONU, 2015). Una educación sobre VIH y sida puede tener mayor efecto cuando se ofrece durante la adolescencia, porque en esta etapa se conforman los rasgos del comportamiento sexual y el discernimiento de riesgos (Folch et al, 2015, p. 472; ShilpaKhanna et al., 2015, p. 194). 
Diseño, implementación y evaluación de un programa de comunicación de riesgos como estrategia de prevención de la infección por VIH en adolescentes

Con base en lo anterior, el objetivo del estudio fue diseñar, implementar y evaluar un PCR como estrategia de educación, para la prevención de la infección por VIH en adolescentes escolarizados de un entorno rural y urbano. Además, se probó la técnica de dibujo, como herramienta para analizar conocimientos y percepciones relacionados con el VIH.

\section{METODOLOGÍA DE INVESTIGACIÓN}

\subsection{Diseño de la investigación}

El estudio fue un ensayo de intervención no aleatorizado, realizado de junio de 2013 a diciembre de 2015. Se sustentó en los pasos y recomendaciones de la CR (Figura 1), llevados a cabo en tres etapas: a) diagnóstico previo; b) diseño e implementación del PCR, y c) evaluación después de la intervención. El tipo de investigación fue mixto, los resultados obtenidos se triangularon para tener una comprensión integral de los conocimientos, percepciones y conductas de riesgo de los estudiantes en relación al VIH (Kaur, 2016; Siddiqui y Fitzgerald, 2014). El proyecto fue aprobado por el Comité de Ética e Investigación en Docencia de la Facultad de Ciencias Químicas de la Universidad Autónoma de San Luis Potosí (Registro CEID2014018). Se siguieron las recomendaciones de la Declaración del Helsinki (AMM, 2013) y las pautas internacionales de la CIOMS (Council for Internacional Organizations of Medical Sciences, 2016).

\subsection{Sitios de estudio}

El estudio se realizó en el estado de San Luis Potosí, localizado en la parte centronorte de la República Mexicana. Se desarrolló en una escuela preparatoria urbana (EPU) del municipio de San Luis Potosí (SLP), y en una escuela preparatoria rural (EPR) del municipio de Tamazunchale. Se seleccionó el municipio de Tamazunchale por tener la incidencia más alta para casos de VIH y de sida, y el municipio de SLP por ser el municipio donde se concentra la mayor parte de la población.

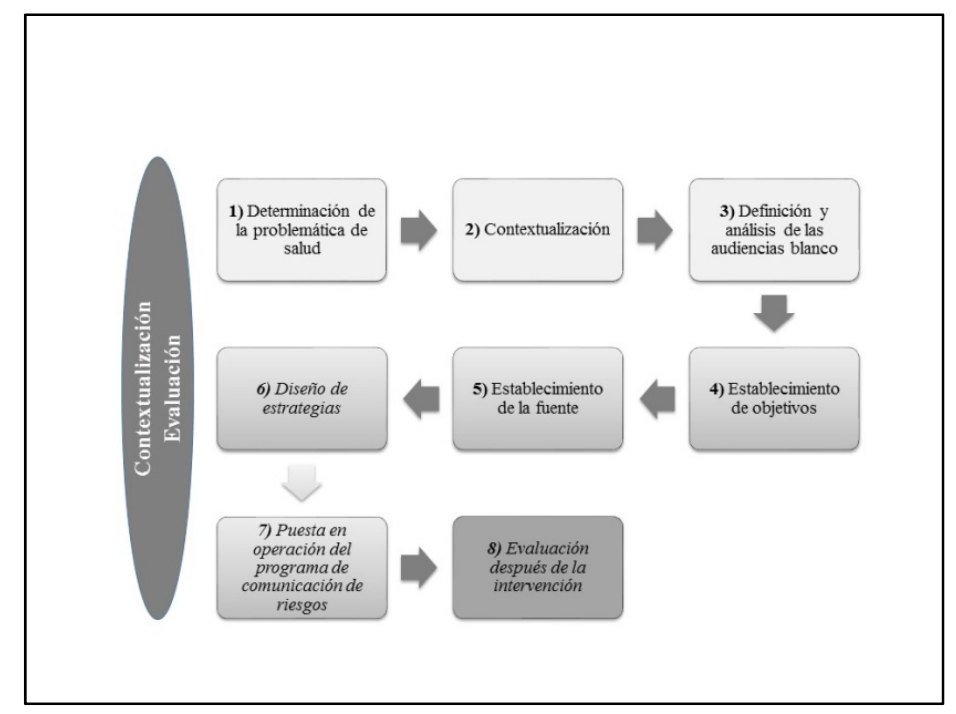


Diseño, implementación y evaluación de un programa de comunicación de riesgos como estrategia de prevención de la infección por VIH en adolescentes

Figura 1. Pasos seguidos en la intervención educativa, basados en la estrategia de Comunicación de Riesgos. San Luis Potosí, México, 2013-2015

Fuente: Elaboración propia basada en Cubillas-Tejeda y González Mares,

\subsection{Diagnóstico previo}

Se realizó un análisis en los adolescentes participantes para conocer su percepción, conocimientos y riesgos de infección por el $\mathrm{VIH}$; se solicitó su consentimiento informado, voluntario y firmado por uno de los padres y por el adolescente. Esta etapa se llevó a cabo de junio de 2013 a mayo de 2014. Se analizó el contexto sociocultural a partir de información recabada de bases de datos del Instituto Nacional de Estadística y Geografía (2016) y del Consejo Nacional de Población (2016). Además, en cada escuela se realizaron entrevistas semiestructuradas a dos maestros, y en el municipio de Tamazunchale se entrevistó también a dos personas residentes del lugar. Se les preguntó sobre los principales problemas relacionados con conductas de riesgo que han detectado en los adolescentes de las escuelas.

\subsubsection{Herramientas de recolección de datos}

Se utilizó un cuestionario conformado por dos apartados: a) Cuatro preguntas abiertas: ¿Cómo defines el síndrome de inmunodeficiencia adquirida?, ¿Qué origina la enfermedad?, ¿Qué provoca la enfermedad en el cuerpo?, y ¿Cómo puedes contraer la enfermedad? b) Un cuestionario de conocimientos y riesgo de infección diseñado de acuerdo a las recomendaciones de la Organización Mundial de la Salud (2004); constó de 18 preguntas de opción múltiple (con 4 a 5 opciones de respuesta), 10 de las cuales fueron de conocimientos. Participaron 177 estudiantes de la EPR y 254 de la EPU (Tabla 1). El cuestionario lo contestaron de forma anónima para que sintieran más confianza.

Se utilizó además la técnica de dibujo, probada previamente para analizar percepción de riesgos a la salud (Meza-Lozano et al., 2016; Terán-Hernández, Díaz-Barriga y Cubillas-Tejeda, 2016). Se solicitó a los adolescentes que respondieran a dos consignas por medio de dibujos: ¿Cómo puedes infectarte con el VIH? y Dibuja las conductas que te pueden proteger de contraer el VIH. Se les proporcionaron hojas, lápices y colores, tuvieron una hora para realizarlo. Participaron 124 estudiantes de la EPR y 190 de la EPU (Tabla 1). Para esta actividad se solicitó que pusieran su nombre, con el fin de hacer comparaciones por estudiante, antes y después de la intervención. 
Diseño, implementación y evaluación de un programa de comunicación de riesgos como estrategia de prevención de la infección por VIH en adolescentes

Tabla 1.

Características de la población de adolescentes participantes en el estudio, agrupados por escuela, San Luis Potosí, México, 2013-2015

\begin{tabular}{|c|c|c|c|c|}
\hline \multirow[b]{2}{*}{ Característica } & \multicolumn{2}{|c|}{$\begin{array}{c}\text { San Luis Potosí } \\
\text { EPU }\end{array}$} & \multicolumn{2}{|c|}{$\begin{array}{c}\text { Tamazunchale } \\
\text { EPR }\end{array}$} \\
\hline & $\begin{array}{l}\text { Antes } \\
\text { PCR }\end{array}$ & $\begin{array}{l}\text { Después } \\
\text { PCR }\end{array}$ & $\begin{array}{l}\text { Antes } \\
\text { PCR }\end{array}$ & $\begin{array}{l}\text { Después } \\
\text { PCR }\end{array}$ \\
\hline $\begin{array}{c}\text { Adolescentes } \\
\text { participantes en el } \\
\text { cuestionario }\end{array}$ & 254 & 202 & 177 & 139 \\
\hline $\begin{array}{c}\text { Porcentaje en relación a } \\
\text { la población total de la } \\
\text { escuela }\end{array}$ & 23.17 & 18.43 & 69.96 & 54.94 \\
\hline $\begin{array}{l}\text { Mujeres participantes en } \\
\text { el cuestionario } \%\left({ }^{a} n\right)\end{array}$ & $63.78(162)$ & $\begin{array}{l}58.41 \\
(118)\end{array}$ & $49.15(87)$ & $45.32(63)$ \\
\hline $\begin{array}{l}\text { Hombres participantes } \\
\text { en el cuestionario } \%\left({ }^{a} n\right)\end{array}$ & $36.22(92)$ & $41.58(84)$ & $50.85(90)$ & $54.68(76)$ \\
\hline $\begin{array}{l}\text { Adolescentes } \\
\text { participantes en la } \\
\text { técnica de dibujo }\end{array}$ & \multicolumn{2}{|c|}{190} & \multicolumn{2}{|c|}{124} \\
\hline $\begin{array}{c}\text { Porcentaje en relación a } \\
\text { la población total de la } \\
\text { escuela }\end{array}$ & \multicolumn{2}{|c|}{17.33} & \multicolumn{2}{|c|}{49.01} \\
\hline $\begin{array}{c}\text { Mujeres participantes en } \\
\text { la técnica de dibujo \% } \\
\left({ }^{a} n\right)\end{array}$ & \multicolumn{2}{|c|}{$63.68(121)$} & \multicolumn{2}{|c|}{$47.58(59)$} \\
\hline $\begin{array}{c}\text { Hombres participantes } \\
\text { en la técnica de dibujo } \\
\%\left({ }^{a} n\right)\end{array}$ & \multicolumn{2}{|c|}{$36.32(69)$} & \multicolumn{2}{|c|}{$52.42(65)$} \\
\hline Rango de edad (años) & $15-18$ & $15-19$ & $15-20$ & $15-20$ \\
\hline
\end{tabular}

${ }^{a}$ Número de adolescentes. Fuente: Elaboración propia

\subsubsection{Análisis de datos}

Las preguntas abiertas del cuestionario se sometieron a análisis de contenido (Silverman, 2016; Taylor, Bogdan y DeVault, 2015), por lo que se establecieron inductivamente categorías temáticas acordes a las respuestas dadas por los adolescentes en cada pregunta. Se realizó por dos codificadores y en los casos en los que hubo diferencia, se ajustaron las categorías por acuerdo. Con base en la clasificación de las respuestas en las diferentes categorías, se obtuvieron las frecuencias de los adolescentes que contestaron en cada una de ellas.

En las preguntas de opción múltiple, las 10 preguntas de conocimientos se calificaron con base a una escala de 0 a 10 puntos. Además, se obtuvo la frecuencia de 
Diseño, implementación y evaluación de un programa de comunicación de riesgos como estrategia de prevención de la infección por VIH en adolescentes

estudiantes que contestó correctamente cada una de las preguntas para tener una idea más clara de los temas en los cuales tienen conocimientos. Para las 8 preguntas restantes, relacionadas con riesgo de infección, se obtuvo la frecuencia de adolescentes que contestó para cada opción dada.

Los dibujos también se sometieron a análisis de contenido, que consistió en analizar los elementos dibujados por cada adolescente en las dos consignas. Con base a los elementos dibujados, se establecieron inductivamente categorías temáticas, y posteriormente los dibujos fueron clasificados en las categorías establecidas y se obtuvieron frecuencias de adolescentes que dibujó en cada categoría.

\subsection{Diseño e implementación del PCR}

Con base en los resultados obtenidos en el diagnóstico, se diseñó el PCR con el fin de promover el aprendizaje significativo en temas relacionados con el VIH y el sida, y el desarrollo de habilidades de autocuidado. Los temas abordados fueron: 1) Sexualidad y género, 2) Sistema inmune, 3) $\mathrm{VIH}$, sida y pruebas diagnósticas, 4) Conductas de riesgo y protección, 5) Trato adecuado a las personas con VIH, 6) ITS, y 7) Relación de pareja, derechos sexuales y reproductivos.

Para la puesta en operación del PCR se siguió la estrategia de educación por pares (Menna, Ali y Worku, 2015; Olave y Villarreal, 2014). En una primera fase el equipo de CR estuvo integrado por los investigadores y la población objetivo estuvo integrada por un grupo de adolescentes ( 6 mujeres y 5 hombres de la EPR; 1 mujer y 7 hombres de la EPU) que voluntariamente aceptaron participar en su capacitación. Con el fin de lograr una educación eficaz (Martínez-Garrido y Murillo, 2016), se seleccionaron distintos medios de comunicación, tales como pláticas apoyadas de presentaciones en computadora, análisis de casos, videos, juegos de mesa (Lotería y Memoria), ejercicios de reflexión y talleres sobre el uso adecuado del condón. Se diseñaron una serie de imágenes icónicas que fueron utilizadas en los distintos medios de comunicación (Figura 2). En la EPU la capacitación de los pares se realizó en tres sesiones de cuatro horas cada una durante febrero y marzo de 2015; en la EPR en dos sesiones de seis horas cada una durante agosto de 2015.

En una segunda fase, la población objetivo estuvo integrada por el resto de los estudiantes de ambas escuelas (253 de la EPR y 1,096 de la EPU). Los estudiantes capacitados prepararon presentaciones sobre los temas de sexualidad, género, $\mathrm{VIH} \mathrm{y}$ sida. Para su divulgación desarrollaron una actividad de 50 minutos que consistió en la presentación oral de los temas y la explicación del uso del condón, apoyándose con material didáctico. La actividad fue presentada en cada uno de los salones de su plantel, con apoyo de los investigadores. También, se realizó una Feria de la salud que consistió en tres módulos de información por los cuales pasaron todos los alumnos. En la EPU los temas manejados en los módulos fueron: 1) Sistema inmunológico, 2) VIH y sida, y 3) personas con VIH; cada módulo tuvo una duración de 20 minutos. En la EPR los temas incluidos fueron: 1) Sexualidad, 2) género, y 3) VIH y sida; cada módulo tuvo una duración de 50 minutos. La selección de temas fue con base a las principales 
Diseño, implementación y evaluación de un programa de comunicación de riesgos como estrategia de prevención de la infección por VIH en adolescentes

necesidades de cada escuela; el tiempo de duración fue el otorgado por los directivos de cada plantel. En la EPU la segunda fase tuvo lugar en abril, y en la EPR durante septiembre y octubre de 2015.

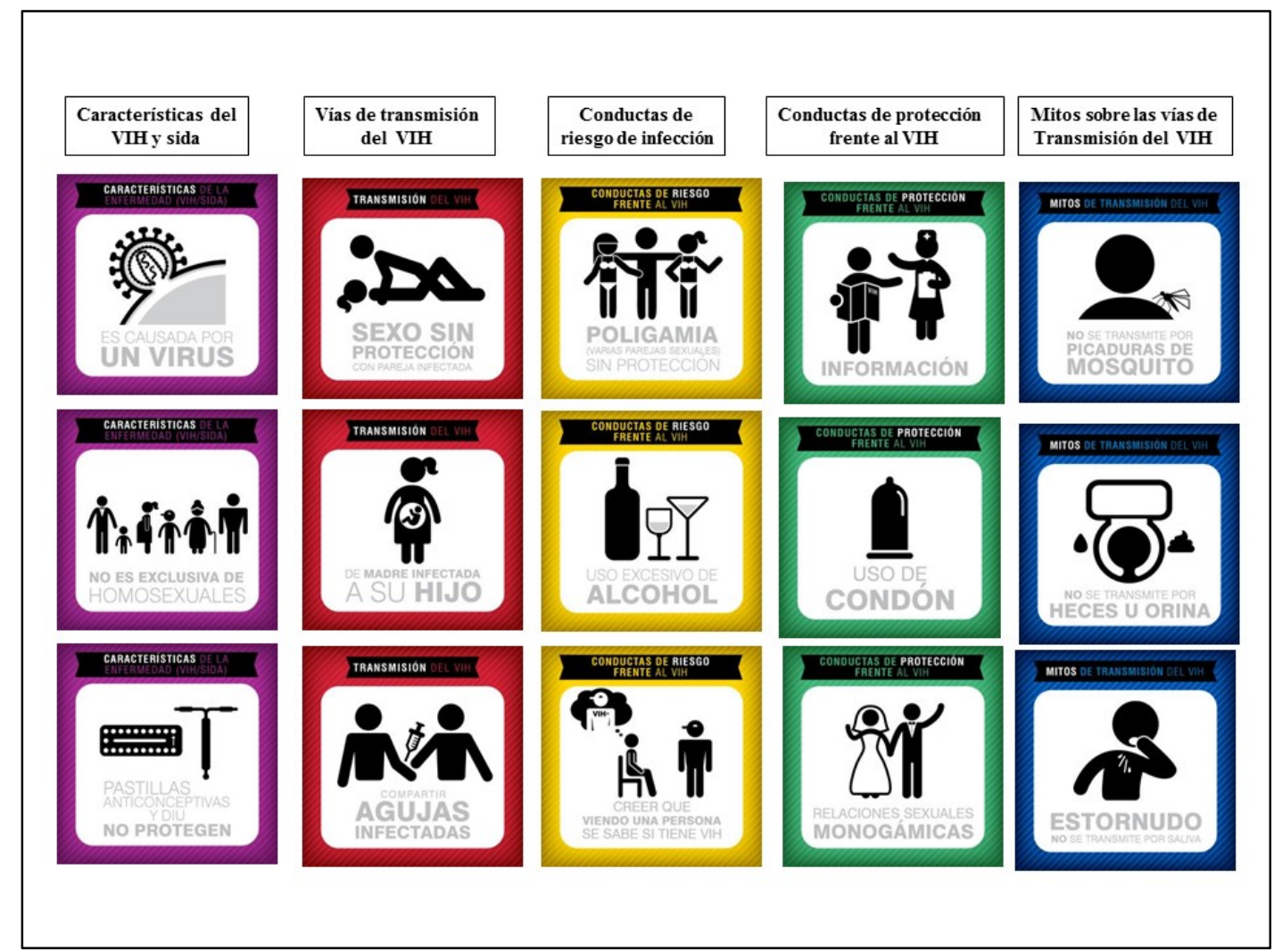

Figura 2. Ejemplos de imágenes icónicas utilizadas en los distintos medios de comunicación empleados en la intervención educativa. San Luis Potosí, México, 20132015 Fuente: Elaboración propia.

\subsection{Evaluación del PCR}

Se utilizaron las mismas herramientas empleadas en el diagnóstico; esta etapa se llevó a cabo en noviembre de 2015. No se trabajó con un grupo control, ya que no se consideró ético dejar sin información a una parte de los adolescentes. El cuestionario se aplicó a 139 de los participantes de la EPR y a 202 de la EPU; el número de participantes disminuyó porque el día de que se aplicó, por diversas razones no asistieron a la escuela. En la técnica del dibujo participaron los mismos estudiantes antes y después del PCR (Tabla 1).

\subsection{Análisis estadístico}

Se utilizó la prueba de Chi-cuadrada para contrastar las proporciones de estudiantes que: a) contestaron en las distintas categorías establecidas para las preguntas abiertas, 
Diseño, implementación y evaluación de un programa de comunicación de riesgos como estrategia de prevención de la infección por VIH en adolescentes

b) contestaron correctamente cada una de las preguntas de opción múltiple del cuestionario. Para comparar las calificaciones obtenidas en el cuestionario se aplicó la prueba ANOVA de una vía; y para los resultados obtenidos en la técnica de dibujo se utilizó la prueba de McNemar. Las comparaciones se hicieron antes y después del PCR: a) dentro de cada escuela, para analizar la efectividad de la intervención, b) entre escuelas, con el objetivo de analizar los aspectos que requieren mayor refuerzo y demostrar que se requiere una intervención contextualizada. El nivel de significancia fue una $p \leq 0.05$. Se utilizó el software JMP® 11 .

\section{RESULTADOS DE LA INVESTIGACIÓN 3.1. Diagnóstico previo}

En el municipio de SLP, donde se localiza la EPU, la mitad de la población total tiene 28 años o menos. En la población de 15 años y más, el $2.7 \%$ no tiene escolaridad. El $86.1 \%$ tiene afiliación a servicios de salud. El grado de marginación del municipio es muy bajo. El $47.9 \%$ de las viviendas cuenta con internet y el $47.2 \%$ con computadora (INEGI, 2016; CONAPO, 2016). Con relación a los maestros entrevistados, refirieron como los principales riesgos para la infección por el VIH en los adolescentes, el alcoholismo, el fácil acceso a drogas y el que algunos adolescentes se pongan tatuajes.

La EPR localizada en el municipio de Tamazunchale, la mitad de la población tiene 25 años o menos. En la población de 15 años y más el $12.4 \%$ no tiene escolaridad. El 92.1\% tiene afiliación a servicios de salud. El municipio de Tamazunchale tiene un grado alto de marginación. El $6.5 \%$ de las viviendas cuenta con internet y el $10.0 \%$ con computadora (INEGI, 2016; CONAPO, 2016). Los principales riesgos en los adolescentes referidos por los maestros y pobladores del lugar, fueron el alcoholismo, la migración al norte del país, el embarazo en la mayoría de las adolescentes, y la falta de actividades recreativas.

En relación a los resultados obtenidos mediante el cuestionario, antes de la intervención se encontró desinformación en los adolescentes sobre las características de la infección por el $\mathrm{VIH}$, además se detectaron conductas de riesgo de infección. En la EPU el $25.20 \%$ de los participantes refirió haber iniciado su vida sexual y en la EPR el $32.77 \%$. En ambas escuelas la edad promedio de inicio de vida sexual fue de 14.8 años (rango 11 a 19 años). De acuerdo a lo referido por los adolescentes que iniciaron su vida sexual, en la EPU el promedio de número parejas fue de 2.14 (rango de 1 a 15), y en la EPR fue 3.38 (rango de 1 a 20). En cuanto al uso de condón en la última relación, en la EPU el $25.00 \%(n=16)$ refirió no utilizarlo y en la EPR el $34.48 \%(n=20)$.

En la Tabla 2 se muestran las categorías establecidas para cada pregunta abierta del cuestionario. La mayoría de los estudiantes mencionaron que el sida es una enfermedad, sin embargo, no saben que el sida es causado por un virus. La mayor parte mostró conocimientos sobre los efectos del VIH y mencionaron la vía sexual de transmisión, pero desconocen las demás vías. Por otro lado, el $9.84 \%$ de los adolescentes de la EPU y el $2.82 \%$ de la EPR señaló vías no relacionadas con la infección del $\mathrm{VIH}$, entre estas la picadura de mosquitos y el uso de baños públicos. 
Diseño, implementación y evaluación de un programa de comunicación de riesgos como estrategia de prevención de la infección por VIH en adolescentes

Además, el $3.94 \%$ de la EPU y el $9.60 \%$ de la EPR refirió como vía de contagio, el contacto con personas infectadas. Al hacer la comparación entre la proporción de alumnos de cada escuela que respondió en cada una de las categorías, se encontraron diferencias estadísticamente significativas.

En las preguntas de opción múltiple, en ambas escuelas la calificación promedio fue menor a 5 puntos (Tabla 3). En la Tabla 4 se muestra el porcentaje de alumnos que contestó correctamente cada una de las preguntas. Se observó que la mayoría de los adolescentes conoce la vía sexual de transmisión; sin embargo, un menor porcentaje sabe que una mujer embarazada puede transmitir el VIH a su bebé. En ambas escuelas más de la mitad de los adolescentes piensan que se pueden contagiar por convivir con personas infectadas, o bien por la picadura de mosquitos u otro tipo de insectos.

Tabla 2.

Adolescentes que respondieron en las categorías establecidas para las preguntas abiertas del cuestionario. San Luis Potosí, México, 2014-2015

\begin{tabular}{|c|c|c|c|c|c|c|c|c|}
\hline \multirow{2}{*}{ Categorías } & \multicolumn{3}{|c|}{ Antes PCR \% $\left(n^{a}\right)$} & \multicolumn{4}{|c|}{ Después PCR \% (n) } & \multirow[b]{2}{*}{$P^{b}$} \\
\hline & $\begin{array}{c}\text { EPU } \\
\mathrm{N}=254\end{array}$ & $\begin{array}{c}\text { EPR } \\
\mathrm{N}=177\end{array}$ & $\mathrm{P}^{\mathrm{b}}$ & $\begin{array}{c}\mathrm{EPU} \\
\mathrm{N}=202\end{array}$ & $\begin{array}{c}\text { EPR } \\
\mathrm{N}=139\end{array}$ & $\begin{array}{c}\mathrm{P}^{\mathrm{c}} \\
\mathrm{EPU}\end{array}$ & $\begin{array}{c}\mathrm{P}^{\mathrm{c}} \\
\mathrm{EPR}\end{array}$ & \\
\hline Pregunta 1 & \multicolumn{8}{|c|}{ ¿Cómo defines el síndrome de inmunodeficiencia adquirida? } \\
\hline Enfermedad & $\begin{array}{l}96.46 \\
(245)\end{array}$ & $\begin{array}{l}84.18 \\
(149)\end{array}$ & $<0.0001$ & $\begin{array}{l}96.04 \\
(194)\end{array}$ & $\begin{array}{l}88.49 \\
(123)\end{array}$ & NS & NS & 0.0074 \\
\hline $\begin{array}{l}\text { Enfermedad } \\
\text { causad por un } \\
\text { virus }\end{array}$ & $0(0)$ & $0(0)$ & NS & $\begin{array}{c}17.33 \\
(35)\end{array}$ & $\begin{array}{c}12.95 \\
(18)\end{array}$ & $<0.0001$ & $\begin{array}{c}<0.000 \\
1\end{array}$ & NS \\
\hline Infección & $0(0)$ & $0(0)$ & NS & $1.00(2)$ & $2.16(3)$ & NS & 0.0495 & NS \\
\hline No sabe & $3.54(9)$ & $\begin{array}{c}15.82 \\
(28)\end{array}$ & $<0.0001$ & $1.48(3)$ & $7.91(11)$ & NS & 0.0339 & 0.0033 \\
\hline Pregunta 2 & \multicolumn{8}{|c|}{ ¿Qué origina la enfermedad? } \\
\hline Virus & $8.66(22)$ & $1.13(2)$ & 0.0008 & $35.64(72)$ & $\begin{array}{c}10.07 \\
(14) \\
\end{array}$ & $<0.0001$ & \begin{tabular}{|c|c|}
1 & 0.000 \\
3
\end{tabular} & $\begin{array}{c}<0.00 \\
01\end{array}$ \\
\hline $\begin{array}{c}\text { Se origina de } \\
\text { los simios }\end{array}$ & $0(0)$ & $0(0)$ & NS & $2.47(5)$ & $0.75(1)$ & 0.0117 & NS & NS \\
\hline $\begin{array}{l}\text { Conductas } \\
\text { que te ponen } \\
\text { en riesgo }\end{array}$ & $\begin{array}{l}49.21 \\
(125)\end{array}$ & $\begin{array}{c}10.73 \\
(19)\end{array}$ & $<0.0001$ & $61.88(125)$ & $\begin{array}{c}68.34 \\
(95)\end{array}$ & 0.0069 & $\begin{array}{c}<0.00 \\
1\end{array}$ & NS \\
\hline No sabe & $\begin{array}{l}42.91 \\
(109)\end{array}$ & $\begin{array}{l}88.14 \\
(156)\end{array}$ & $<0.0001$ & $8.42(17)$ & $\begin{array}{c}24.46 \\
(34)\end{array}$ & $<0.0001$ & \begin{tabular}{|c|c|}
1 & $<0.00$ \\
1
\end{tabular} & $\begin{array}{c}<0.00 \\
01\end{array}$ \\
\hline Pregunta 3 & \multicolumn{8}{|c|}{ ¿Qué provoca la enfermedad en el cuerpo? } \\
\hline Muerte & $24.80(63)$ & $\begin{array}{c}43.50 \\
(77)\end{array}$ & $<0.0001$ & $9.90(20)$ & $7.91(11)$ & $<0.0001$ & \begin{tabular}{|c|c|}
1 & $<0.00$ \\
1
\end{tabular} & NS \\
\hline $\begin{array}{l}\text { Síntomas } \\
\text { físicos }\end{array}$ & $27.56(70)$ & $\begin{array}{c}37.85 \\
(67)\end{array}$ & 0.024 & $21.28(43)$ & $\begin{array}{c}34.53 \\
(48)\end{array}$ & NS & NS & $\begin{array}{c}0.006 \\
6\end{array}$ \\
\hline
\end{tabular}


Diseño, implementación y evaluación de un programa de comunicación de riesgos como estrategia de prevención de la infección por VIH en adolescentes

\begin{tabular}{|c|c|c|c|c|c|c|c|c|}
\hline $\begin{array}{c}\text { Daños a } \\
\text { órganos o } \\
\text { sistemas }\end{array}$ & $\begin{array}{l}44.49 \\
(113)\end{array}$ & $\begin{array}{c}25.42 \\
(45)\end{array}$ & $<0.0001$ & $60.89(123)$ & $\begin{array}{c}36.69 \\
(51)\end{array}$ & 0.0005 & $\begin{array}{c}0.030 \\
6\end{array}$ & $\begin{array}{c}<0.00 \\
01\end{array}$ \\
\hline $\begin{array}{c}\text { Enfermedade } \\
\text { s o } \\
\text { infecciones }\end{array}$ & $20.87(53)$ & $6.21(11)$ & $<0.0001$ & $22.28(45)$ & $\begin{array}{c}15.11 \\
(21)\end{array}$ & NS & $\begin{array}{c}0.009 \\
3\end{array}$ & NS \\
\hline No sabe & $21.65(55)$ & $\begin{array}{c}20.90 \\
(37)\end{array}$ & NS & $14.36(29)$ & $\begin{array}{c}20.14 \\
(28) \\
\end{array}$ & 0.0459 & NS & NS \\
\hline Pregunta 4 & \multicolumn{8}{|c|}{ ¿Cómo puedes contraer la enfermedad? } \\
\hline Vía sexual & $\begin{array}{l}90.55 \\
(230)\end{array}$ & $\begin{array}{l}84.18 \\
(149)\end{array}$ & NS & $87.13(176)$ & $\begin{array}{l}74.82 \\
(104)\end{array}$ & NS & $\begin{array}{c}0.038 \\
7\end{array}$ & $\begin{array}{c}0.003 \\
6\end{array}$ \\
\hline Vía perinatal & $9.05(23)$ & $1.69(3)$ & 0.0016 & $13.86(28)$ & $4.32(6)$ & NS & NS & $\begin{array}{c}0.003 \\
8\end{array}$ \\
\hline Vía sanguínea & $\begin{array}{l}43.31 \\
(110)\end{array}$ & $\begin{array}{c}38.98 \\
(69)\end{array}$ & NS & $69.31(140)$ & $\begin{array}{c}41.01 \\
(57)\end{array}$ & $<0.0001$ & NS & $\begin{array}{c}<0.00 \\
01\end{array}$ \\
\hline $\begin{array}{l}\text { Vías no } \\
\text { relacionadas } \\
\text { al VIH }\end{array}$ & $9.84(25)$ & $2.82(5)$ & 0.0049 & 4.95 (10) & $5.75(8)$ & NS & NS & NS \\
\hline $\begin{array}{c}\text { Contacto con } \\
\text { personas con } \\
\text { VIH }\end{array}$ & $3.94(10)$ & $9.60(17)$ & 0.0169 & $0.49(1)$ & $0.72(1)$ & 0.0173 & $\begin{array}{c}0.000 \\
7\end{array}$ & NS \\
\hline No sabe & $4.33(11)$ & $\begin{array}{c}15.82 \\
(28)\end{array}$ & $<0.0001$ & 8.42 (17) & $\begin{array}{c}15.11 \\
(21)\end{array}$ & NS & NS & NS \\
\hline
\end{tabular}

PCR, Programa de Comunicación de Riesgos; EPU, escuela preparatoria urbana; EPR, escuela preparatoria rural; NS, no significativo $(P>0.05) .{ }^{a}$ Número de adolescentes que respondió en cada categoría. ${ }^{\mathrm{b}}$ Comparación entre escuelas, antes y después del $\mathrm{PCR}$, valor de $\mathrm{p}$ obtenido por la prueba Chi cuadrada. ${ }^{\mathrm{C}}$ Comparación antes y después del PCR dentro de cada escuela, valor de $\mathrm{p}$ obtenido por la prueba por Chi cuadra. Fuente: elaboración propia.

Tabla 3.

Calificación obtenida por los participantes en el cuestionario de conocimientos, antes y después de la intervención. San Luis Potosí, México, 2014-2015

\begin{tabular}{|c|c|c|c|c|c|c|}
\hline & \multicolumn{2}{|c|}{ Antes PCR } & \multicolumn{4}{c|}{ Después PCR } \\
\hline Escuela & $\mathrm{N}^{\mathrm{a}}$ & $\mathrm{X}^{\mathrm{b}}(\mathrm{DE})$ & $\mathrm{N}$ & $\mathrm{X}(\mathrm{DE})$ & Valor $\mathrm{F}$ & $\mathrm{P}^{\mathrm{c}}$ \\
\hline EPU & 254 & $4.90(1.737)$ & 202 & $6.53(1.840)$ & 96.483 & $<0.0001$ \\
\hline EPR & 177 & $3.81(1.771)$ & 139 & $4.80(2.174)$ & 16.728 & $<0.0001$ \\
\hline Valor $\mathrm{F}^{\mathrm{d}}$ & & 40.230 & & 71.573 & & \\
\hline $\mathrm{P}^{\mathrm{e}}$ & & $<0.00001$ & & $<0.00001$ & & \\
\hline
\end{tabular}

PCR, Programa de Comunicación de Riesgos; EPU, escuela preparatoria urbana; EPR, escuela preparatoria rural; DE, desviación estándar. a Número de alumnos participantes. ${ }^{\mathrm{b}}$ Media de las calificaciones obtenidas. ${ }^{\mathrm{C}}$ Valor de $\mathrm{P}$ al comparar las 
Diseño, implementación y evaluación de un programa de comunicación de riesgos como estrategia de prevención de la infección por VIH en adolescentes

calificaciones, antes y después del PCR, dentro de cada escuela. ${ }^{\mathrm{d}}$ Valor obtenido por la prueba ANOVA de una vía. ${ }^{\mathrm{e}}$ Valor de $\mathrm{P}$ al comparar las calificaciones obtenidas entre las escuelas. Fuente: elaboración propia.

Tabla 4.

Adolescentes que respondieron correctamente a las preguntas de opción múltiple del cuestionario de conocimientos. San Luis Potosí, México, 2014-2015

\begin{tabular}{|c|c|c|c|c|c|c|}
\hline PCR & EPU & EPR & $P^{a}$ & EPU & EPR & $P^{a}$ \\
\hline & \multicolumn{3}{|c|}{ Diferencia entre VIH y sida } & \multicolumn{3}{|c|}{$\begin{array}{l}\text { Puede sentirse y verse saludable una } \\
\text { persona con } \mathrm{VIH}\end{array}$} \\
\hline Antes $\%\left(n^{b}\right)$ & $43.31(110)$ & $28.81(51)$ & $<0.0001$ & $23.23(59)$ & $12.99(23)$ & 0.0077 \\
\hline Después \% (n) & $78.22(158)$ & $43.88(61)$ & $<0.0001$ & $46.04(93)$ & $27.33(38)$ & 0.0005 \\
\hline \multirow[t]{2}{*}{$P^{c}$} & $<0.0001$ & 0.0054 & & $<0.0001$ & 0.0013 & \\
\hline & \multicolumn{3}{|c|}{$\begin{array}{l}\text { El sida puede reducir la protección del } \\
\text { cuerpo contra la enfermedad }\end{array}$} & \multicolumn{3}{|c|}{$\begin{array}{l}\text { Puede transmitir una mujer } \\
\text { embarazada el VIH a su bebé }\end{array}$} \\
\hline Antes \% (n) & $40.94(104)$ & $27.12(48)$ & 0.0031 & $58.66(149)$ & $56.49(100)$ & NS \\
\hline Después \% (n) & $59.41(120)$ & $35.97(50)$ & $<0.0001$ & $59.90(121)$ & $55.39(77)$ & NS \\
\hline \multirow[t]{2}{*}{$\mathrm{P}^{\mathrm{C}}$} & $<0.0001$ & NS & & NS & NS & \\
\hline & \multicolumn{3}{|c|}{$\begin{array}{l}\text { Puede tener una persona } \mathrm{VIH} \text { y no tener } \\
\text { sida }\end{array}$} & \multicolumn{3}{|c|}{$\begin{array}{l}\text { Es probable contraer el VIH al } \\
\text { convivir con alguien que tiene VIH }\end{array}$} \\
\hline Antes \% (n) & $17.32(44)$ & $13.55(24)$ & NS & $44.49(113)$ & $29.37(52)$ & 0.0015 \\
\hline Después \% (n) & $42.08(85)$ & $23.02(32)$ & 0.0003 & $54.45(110)$ & $43.16(60)$ & NS \\
\hline \multirow[t]{2}{*}{$\mathrm{P}^{\mathrm{c}}$} & $<0.0001$ & 0.0288 & & 0.0261 & 0.011 & \\
\hline & \multicolumn{3}{|c|}{$\begin{array}{l}\text { Se puede saber si una persona tiene } \\
\text { VIH al mirarla }\end{array}$} & \multicolumn{3}{|c|}{$\begin{array}{l}\text { Se puede contraer VIH al compartir } \\
\text { agujas para inyectarse drogas }\end{array}$} \\
\hline Antes \% (n) & $64.57(164)$ & $42.93(76)$ & $<0.0001$ & $89.76(228)$ & $77.96(138)$ & 0.0008 \\
\hline Después \% (n) & $77.23(156)$ & $47.48(66)$ & $<0.0001$ & $94.06(190)$ & $84.89(118)$ & 0.0049 \\
\hline \multirow[t]{2}{*}{$\mathrm{P}^{\mathrm{c}}$} & 0.0018 & NS & & 0.0404 & 0.0034 & \\
\hline & \multicolumn{3}{|c|}{$\begin{array}{c}\text { Se puede transmitir el VIH en el acto } \\
\text { sexual }\end{array}$} & \multicolumn{3}{|c|}{$\begin{array}{l}\text { Se puede contraer VIH por picadura } \\
\text { de un mosquito u otro insecto }\end{array}$} \\
\hline Antes \% (n) & $87.01(221)$ & $85.31(151)$ & NS & $20.87(53)$ & $22.03(39)$ & NS \\
\hline Después \% (n) & $89.60(181)$ & $80.57(112)$ & 0.0185 & $45.54(92)$ & $15.10(21)$ & $<0.0001$ \\
\hline $\mathrm{P}^{\mathrm{c}}$ & NS & NS & & $<0.0001$ & NS & \\
\hline
\end{tabular}

PCR, Programa de Comunicación de Riesgos; EPU, escuela preparatoria urbana; EPR, escuela preparatoria rural; NS, no significativo $(P>0.05)$. ${ }^{a}$ Valor de $P$ obtenido por la prueba por Chi cuadrada al comparar entre escuelas. ${ }^{b}$ Número de adolescentes que respondió correctamente 
Diseño, implementación y evaluación de un programa de comunicación de riesgos como estrategia de prevención de la infección por VIH en adolescentes

a la pregunta. ${ }^{\mathrm{C}}$ Valor de $\mathrm{P}$ obtenido por la prueba por Chi cuadrada al comparar antes y después del PCR. Fuente: elaboración propia.

En la técnica de dibujo, para la pregunta ¿Cómo puedes infectarte con el VIH? se establecieron seis categorías (Figura 3). La mayoría de los estudiantes dibujó en la categoría Transmisión sanguínea. En la categoría Transmisión sexual dibujó un mayor porcentaje $(p<0.0001)$ de participantes de la EPU $(65.26 \%)$ en comparación con los participantes de la EPR (40.32\%). Se encontró que el $10.0 \%$ de los estudiantes de la EPU dibujó elementos dentro de la categoría Transmisión materna, y ninguno de la EPR $(p=0.0001)$. Existen alumnos que refirieron como vía de contagio otras no relacionadas con la transmisión del $\mathrm{VIH}$, como la picadura de mosquitos y el uso de baños públicos (Figura 4A y $4 \mathrm{C}$ ). Además, se encontró que el $2.63 \%$ de la EPU y el $2.42 \%$ de la EPR señaló como vía de infección el convivir con personas infectadas.

Para la consigna Dibuja las conductas que te pueden proteger de contraer VIH se establecieron 6 categorías (Figura 5). En la categoría Uso de condón fue en la que dibujó la mayoría de los estudiantes. También se encontró un mayor porcentaje de estudiantes de la EPU $(p<0.0001)$ que refirió el uso de jeringas nuevas $(23.68 \%)$ y la abstinencia (29.47\%). Por otro lado, el $21.58 \%$ de la EPU y el $26.61 \%$ de la EPR dibujaron elementos en la categoría Otras conductas de protección no relacionadas al $\mathrm{VIH}$ tales como medidas de higiene (Figura 4E) y pastillas anticonceptivas (Figura 4G).

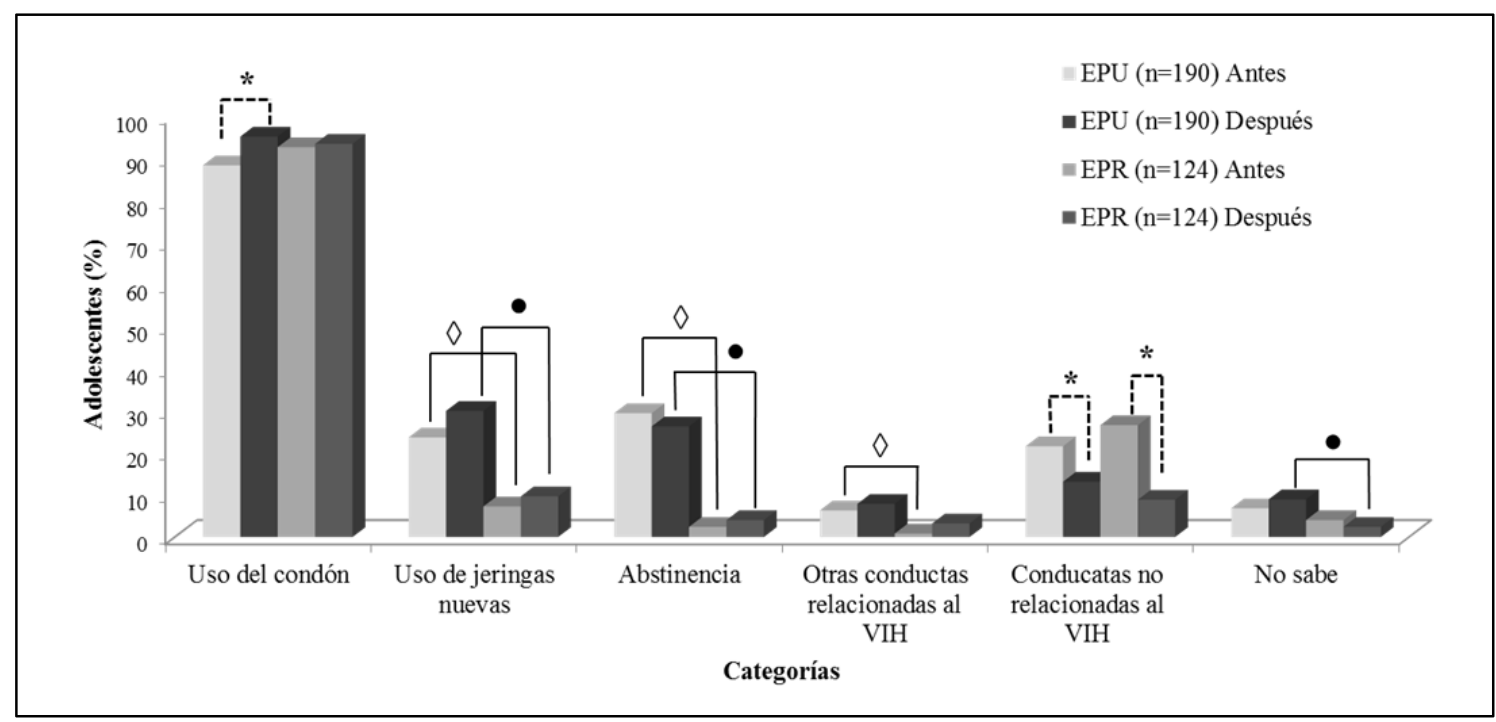

Figura 3. Adolescentes que respondieron, antes y después de la intervención, en las categorías establecidas para la pregunta ¿Cómo puedes infectarte con el virus de inmunodeficiencia humana? en la técnica de dibujo. San Luis Potosí, México, 2014-2015 EPU, escuela preparatoria urbana; EPR, escuela preparatoria rural; $n$, número total de adolescentes.

* Comparación antes y después de la intervención, valor de $\mathrm{P} \leq 0.05$ obtenido por la prueba de McNemar. $\diamond$ Comparación EPU vs EPR antes de la intervención, valor de $P \leq 0.05$ obtenido por la prueba Chi-cuadrada. - Comparación EPU vs EPR después de la 
Diseño, implementación y evaluación de un programa de comunicación de riesgos como estrategia de prevención de la infección por VIH en adolescentes

intervención, valor de $\mathrm{P} \leq 0.05$ obtenido por la prueba Chi-cuadrada. Fuente: elaboración propia.

Dibujos de dos adolescentes en respuesta a la pregunta

¿Cómo puedes infectarte con el virus de la inmunodeficiencia humana (VIH)?

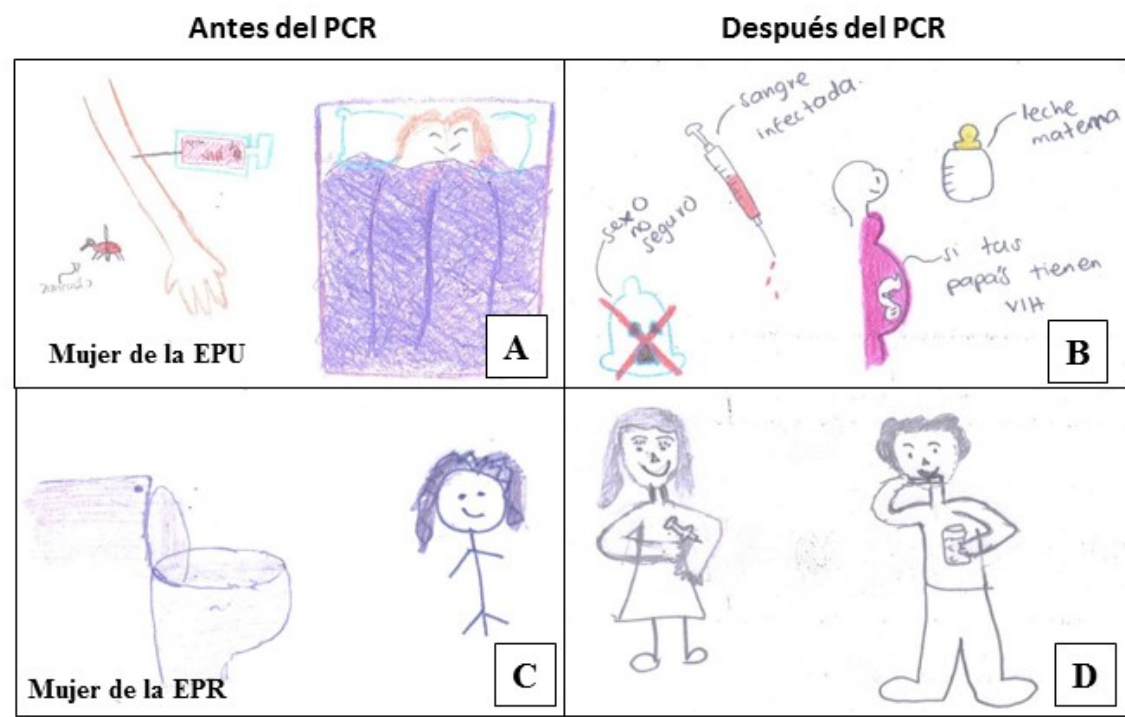

Dibujos de dos adolescentes en respuesta a la consigna Dibuja las conductas que te pueden proteger de contraer VIH

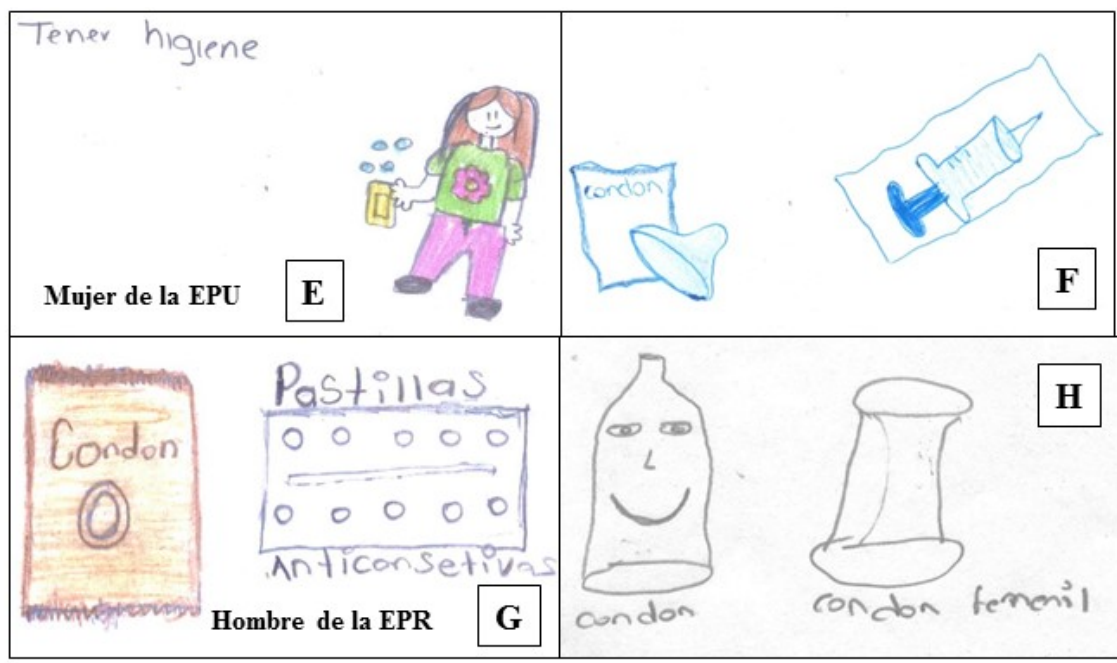

Figura 4. Ejemplos de dibujos realizados por los adolescentes antes y después del Programa de Comunicación de Riesgos, San Luis Potosí, México, 2014-2015 Fuente: elaboración propia 
Diseño, implementación y evaluación de un programa de comunicación de riesgos como estrategia de prevención de la infección por VIH en adolescentes

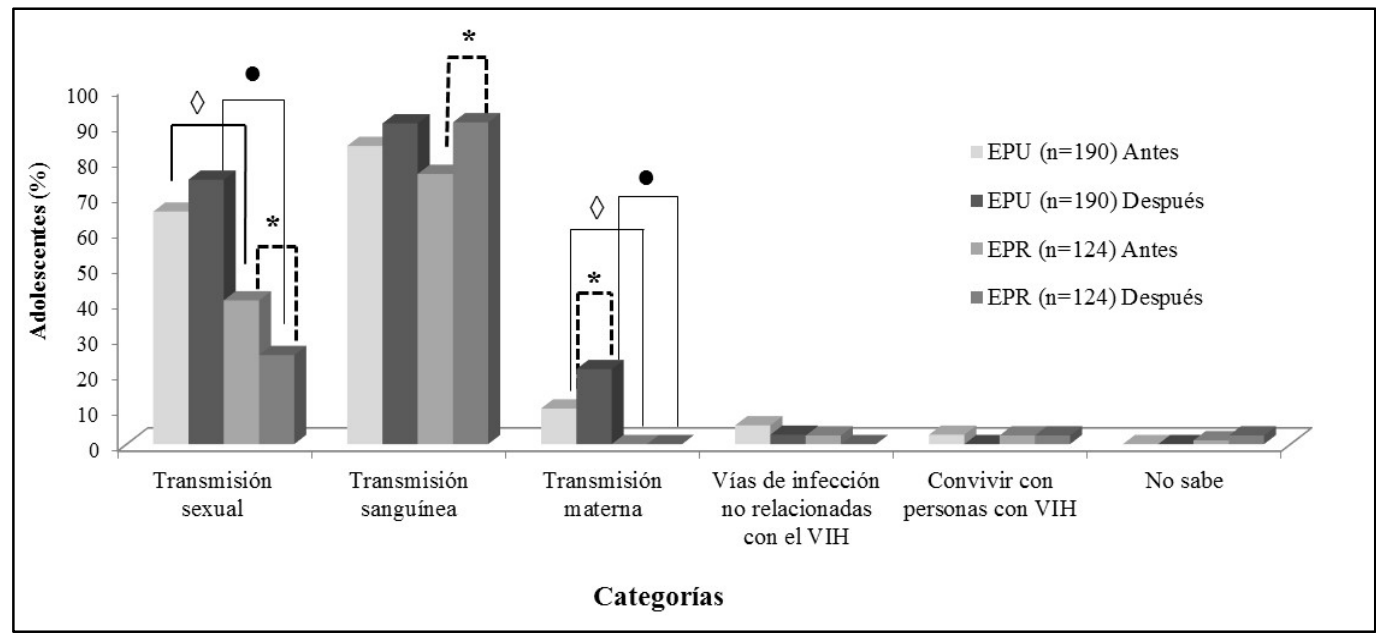

Figura 5. Adolescentes que respondieron, antes y después de la intervención, en las categorías establecidas para la consigna "Dibuja las conductas que te pueden proteger de contraer el VIH", en la técnica de dibujo. San Luis Potosí, México, 2014-2015

EPU, escuela preparatoria urbana; EPR, escuela preparatoria rural; $n$, número total de adolescentes.

* Comparación antes y después de la intervención, valor de $\mathrm{P} \leq 0.05$ obtenido por la prueba de McNemar. $\diamond$ Comparación EPU vs EPR antes de la intervención, valor de $\mathrm{P} \leq 0.05$ obtenido por la prueba Chi-cuadrada. - Comparación EPU vs EPR después de la intervención, valor de $\mathrm{P} \leq 0.05$ obtenido por la prueba Chi-cuadrada. Fuente: elaboración propia.

\subsection{Evaluación del PCR}

En las preguntas abiertas del cuestionario, los resultados sugieren que después de la intervención, los estudiantes integraron conocimientos relacionados con el VIH y el sida (Tabla 2). En la pregunta ¿Cómo defines el síndrome de inmunodeficiencia adquirida?, se encontró un aumento significativo en el porcentaje de adolescentes que lo definió como una enfermedad causada por un virus. Por otro lado, disminuyó el porcentaje de adolescentes que no supo definirlo, y la diferencia fue estadísticamente significativa para la EPU. En la pregunta ¿Qué origina la enfermedad?, se encontró un aumento estadísticamente significativo en el porcentaje de alumnos que señaló que el sida se origina por un virus. También se incrementó el porcentaje de alumnos que relacionó al sida con conductas de riesgo, tales como, relaciones sexuales sin protección, el alcoholismo, o el consumir drogas.

Referente a la pregunta ¿Qué provoca la enfermedad en el cuerpo?, se encontró un incremento significativo en el porcentaje de estudiantes que refirió que el VIH afecta órganos y sistemas, y en el porcentaje de la EPR que refirió que provoca infecciones por diferentes microorganismos. Por otro lado, disminuyó significativamente el porcentaje de estudiantes que señaló al sida como una enfermedad mortal, y el porcentaje de adolescentes de la EPU que no supo contestar. En la pregunta ¿Cómo puedes contraer la enfermedad?, se encontró un aumento significativo en el porcentaje de estudiantes de la EPU que mencionó la vía sanguínea; y una disminución 
Diseño, implementación y evaluación de un programa de comunicación de riesgos como estrategia de prevención de la infección por VIH en adolescentes

significativa en el porcentaje de estudiantes de ambas escuelas que mencionó como vía de contagio el contacto con personas infectadas. En las cuatro preguntas, después de la intervención, se encontraron diferencias significativas entre las escuelas, lo que sugiere que un mayor porcentaje de adolescentes de la EPU integraron conocimientos relacionados con el VIH y el sida.

En las preguntas de opción múltiple, después del PCR se incrementó de manera estadísticamente significativa $(p<0.00001)$ la media de la calificación obtenida por los estudiantes (Tabla 3). No obstante, el promedio de la calificación de los estudiantes de la EPU fue estadísticamente mayor que el de los estudiantes de la EPR ( $p<0.00001)$. Al analizar cada una de las 10 preguntas realizadas, se observó que después del programa un mayor porcentaje de adolescentes de la EPU respondió correctamente, la diferencia fue significativa en 6 preguntas. En la EPR el porcentaje de adolescentes que respondió correctamente después del PCR fue mayor en 7 preguntas, en 4 de éstas la diferencia fue estadísticamente significativa. A pesar de ello, al comparar entre las escuelas, se encontró un porcentaje mayor de participantes de la EPU que respondió correctamente en todas las preguntas, en 8 de ellas la diferencia fue estadísticamente significativa (Tabla 4).

En la técnica de dibujo, para la pregunta ¿Cómo puedes infectarte con el virus de inmunodeficiencia humana?, en la EPU después del PCR se observó un aumento no significativo en el porcentaje de estudiantes que dibujó en las categorías Transmisión sexual y Transmisión sanguínea, y un aumento estadísticamente significativo en el porcentaje que dibujó en la categoría Transmisión materna. Además, no se encontraron dibujos en la categoría de Convivir con personas infectadas. En la EPR se encontró, después de la intervención, un aumento significativo en el porcentaje de adolescentes que dibujó en la categoría Transmisión sanguínea; y contrario a lo esperado, disminuyó de manera significativa el porcentaje de adolescentes que dibujó en la categoría Transmisión sexual. Al comparar entre las escuelas, se encontró un porcentaje significativamente mayor de adolescentes de la EPU que dibujó en las categorías Transmisión sexual y Transmisión materna (Figura 3 y Figuras 4A y 4D).

Para la consigna Dibuja las conductas que te pueden proteger de contraer VIH, la categoría Uso de condón fue en la que un mayor porcentaje de adolescentes dibujó; en la EPU se observó un incremento significativo $(\mathrm{p}=0.0123)$ después de la intervención (Figura 5, y Figuras 4F y $4 \mathrm{H}$ ). Se encontró que más del $20 \%$ de los adolescentes de la EPU dibujó en las categorías Uso de jeringas nuevas y Abstinencia, pero no se encontraron cambios significativos después de la intervención. Asimismo, se encontraron diferencias significativas entre las escuelas al comparar el porcentaje de estudiantes que dibujó en dichas categorías después de la intervención. En la categoría Otras conductas de protección no relacionadas al VIH, se encontró que después del PCR disminuyó significativamente el porcentaje de alumnos que dibujó (EPU $p=0.0375$; EPR $p=0.0108)$. 
Diseño, implementación y evaluación de un programa de comunicación de riesgos como estrategia de prevención de la infección por VIH en adolescentes

\section{DISCUSIÓN}

El estudio se basó en el problema de salud relacionado con el $\mathrm{VIH}$ y el sida, así como en el riesgo de infección por VIH en la población adolescente. La situación de los adolescentes analizados en el presente estudio es similar a la de otros adolescentes en México, América Latina y el resto del mundo (Conde-Ferráez et al., 2016; UNFPA, 2016, UNAIDS, 2016; Quevedo-Gómez et al., 2011; Berrio, 2014; Zambrano et al., 2013; Pavía-Ruz et al., 2012;). A pesar de que se han realizado diversas estrategias de prevención (Widman et al., 2016; Tello y Campos, 2015; Logie et al., 2014; St. Lawrence et al., 2013; Barros et al., 2001), es indiscutible la necesidad continuar con la búsqueda de estrategias contextualizadas e innovadoras, que puedan ser efectivas para la población adolescente (OMS, 2016, UNAIDS, 2016; ONU, 2015). Es indispensable buscar nuevas maneras de educar a los adolescentes en temas de sexualidad, igualdad de género y autocuidado, involucrando a compañeros, docentes y padres capacitados.

Por lo anterior, en la presente investigación se diseñó, implementó y evaluó un PCR como estrategia de educación para la salud sobre la prevención de la infección por VIH, dirigida a población adolescente. Con base en los pasos de CR propuestos (CubillasTejeda y González Mares, 2015), se realizó el diagnóstico previo de la audiencia blanco, sobre percepción de riesgos, conocimientos y conductas de riesgo de infección por el $\mathrm{VIH}$. Mediante la triangulación de los resultados obtenidos en las distintas herramientas de recolección de datos, se pudo apreciar que algunos estudiantes de SLP y de Tamazunchale sí mostraron conocimientos sobre el VIH y sida, sin embargo, todavía se observó desinformación al respecto. Por ejemplo, algunos adolescentes mostraron conocimientos equivocados sobre las vías de infección y las conductas que los pueden proteger, lo cual puede incrementar su riesgo de infección.

Adicionalmente, se detectaron conductas de riesgos en los adolescentes de las dos preparatorias, entre éstas, el inicio temprano de la vida sexual (11-19 años) en más de la cuarta parte de los adolescentes analizados; el tener varias parejas sexuales, y la falta de uso de condón en la última relación sexual referida por los adolescentes que iniciaron su vida sexual. Aunado a lo anterior, de acuerdo a lo referido por los maestros y personas entrevistadas, se detectaron factores que incrementan el riesgo de infección por VIH y otras ITS; en SLP varios jóvenes suelen tatuarse, existe alcoholismo y consumo de drogas; en Tamazunchale el alcoholismo en jóvenes y una alta migración a los Estados Unidos.

El analizar el contexto sociocultural y realizar un diagnóstico previo al diseño del PCR, hizo posible adecuarlo a las necesidades de los adolescentes de cada zona. Se diseñaron los mensajes, y se seleccionaron diferentes medios de comunicación para favorecer una educación eficaz, en este sentido se ha reportado que los PCR que han sido efectivos han utilizado diversos medios de comunicación (Vallejos-Romero y Oñate-Ñancucheo, 2013; Fitzpatrick-Lewis et al., 2010). Después de la intervención, aunque no en todos los casos, los adolescentes percibieron riesgos e integraron 
Diseño, implementación y evaluación de un programa de comunicación de riesgos como estrategia de prevención de la infección por VIH en adolescentes

conocimientos relacionados con el VIH y el sida. No obstante, todavía es evidente la falta de conocimientos en un alto porcentaje de estudiantes principalmente en la EPR.

Los resultados encontrados pueden deberse a limitaciones en el estudio, entre las que cabe señalar que durante la fase de intervención se contó con muy poco tiempo, debido a cuestiones internas en cada centro escolar, por lo que se deberá gestionar más tiempo para la implementación del PCR, o bien, integrar las actividades dentro de las asignaturas impartidas en las escuelas. Durante todo el proceso del PCR en las dos preparatorias se logró la participación de los directivos y maestros, aunque no se logró la participación de los padres de familia, a pesar de que se hicieron invitaciones. Posibles explicaciones al respecto son que quizás los padres de familia por cuestiones de trabajo no pudieron asistir cuando se les convocó; otra explicación es que la mayoría de los padres pierden atención en sus hijos conforme van creciendo; o bien porque no se logró convocar y motivar lo suficiente a los padres de familia. Este punto deberá mejorarse en futuras intervenciones, pues su participación podría favorecer el diálogo con los adolescentes (Martínez-Garrido y Murillo, 2016:485).

Un aporte relevante de la investigación fue el seleccionar diversas herramientas de recolección de datos, lo que permitió la triangulación de resultados; se observó que los resultados obtenidos mediante el cuestionario (anónimo) y el dibujo (no anónimo) fueron similares. La estrategia de educación por pares es otra fortaleza del estudio; las actividades que los alumnos realizaron, favorecieron que sus compañeros se interesaran por el tema y tuvieran la confianza de expresar sus dudas y preocupaciones. Lo anterior coincide con otras investigaciones en las que se señala que los programas de educación sobre salud para compañeros son una estrategia efectiva para mejorar los conocimientos en adolescentes (Moshki, Zamani-Alavijeh y Mojadam, 2017; Tosin y Tshitangano, 2016; UNAIDS, 2016; Menna, Ali y Worku, 2015).

\section{CONCLUSIONES}

De acuerdo a los resultados obtenidos se sugiere que la CR puede ser es una estrategia educativa efectiva para la prevención de la infección por VIH en adolescentes. Para que sea eficaz, se requiere considerar el contexto sociocultural y, el análisis de la percepción de riesgos, conocimientos y conductas de riesgos de infección en los adolescentes. Este diagnóstico previo puede servir como línea base para la evaluación de la intervención. Se recomienda, en su diseño e implementación, favorecer el aprendizaje significativo y promover habilidades de autocuidado en los adolescentes. El desarrollo de dibujos mostró ser una herramienta útil para el análisis de conocimientos y percepción de riesgos relacionadas con el $\mathrm{VIH}$, y el hecho de no ser anónimo, permitió la evaluación individual de cada estudiante, antes y después de la intervención. 
Diseño, implementación y evaluación de un programa de comunicación de riesgos como estrategia de prevención de la infección por VIH en adolescentes

\section{REFERENCIAS}

Asociación Médica Mundial (2013). Declaración de Helsinki de la AMM- Principios éticos para las investigaciones médicas en seres humanos. Recuperado de https://www.wma.net/es/que-hacemos/etica-medica/declaracion-de-helsinki/.

Barros, T., Dimitri, B., Pérez, F., Santander, R., Yépez, E., Abad-Franch, F. y Aguilar M. (2001). Un modelo de prevención primaria de las enfermedades de transmisión sexual y del VIH/sida en adolescentes. Revista Panamericana de Salud Pública, 10(2), 86-94. doi:10.1590/S1020-49892001000800003.

Berrio, Edilma: Armién, Blas y Stanziola, Domingo. (2014). Crecer sin VIH: Prevenir con educación. Panamá: UNFPA-ICGES.

Conde-Ferráez, L., Moo, F., Polanco, L. y González, M (2016). Aplicación de un instrumento electrónico para identificar conductas sexuales de riesgo en estudiantes universitarios. Revista de Comunicación y Salud, 6, 15-27. doi: 10.1177/0009922811423311.

Consejo Nacional de Población (2016). Índice de marginación por entidad federativa y municipio 2015. México: CNP. Recuperado de http://www.gob.mx/conapo/documentos/indice-de-marginacion-por-entidadfederativa-y-municipio-2015.

Council for International Organizations of Medical Sciences y World Health Organization (2016). Pautas Internacionales para la Investigación Biomédica en seres humanos. Recuperado de https://cioms.ch/shop/product/international-ethical-guidelines-forhealth-related-research-involving-humans/.

Cubillas-Tejeda, A. y González-Mares, M. (2015). La comunicación de riesgos como estrategia de intervención para mejorar la salud ambiental en poblaciones vulnerables. En: A. Mendieta, P. Testas, (eds.). ¿Legitimidad o reconocimiento? Las investigadores del SNI: retos y propuestas (pp. 489-496). México, DF: Benemérita Universidad Autónoma de Puebla, Ediciones La Biblioteca

Fitzpatrick-Lewis, D., Yost, J., Ciliska, J. y Krishnaratne, S. (2010). Communication about environmental health risks: A systematic review. Environmental Health, 9, 115. doi: 0.1186/1476-069X-9-67.

Folch, C., Álvarez, J. L., Casabona, J., Brotons, M., Castellsagué, X. y Grupo Jóvenes e Internet (2015). Determinantes de las conductas sexuales de riesgo en jóvenes de Cataluña. Revista Española de Salud Pública, 89, 471-485. doi: 10.4321/S113557272015000500005.

Hanass-Hancock, J. (2014). Tangible skill building and HIV youth prevention intervention in rural South Africa. African Journal of AIDS Research, 8(3), 229-235. doi: 10.2989/16085906.2014.952647

Instituto Nacional de Estadística y Geografía (2016). Encuesta Intercensal 2015: Panorama sociodemográfico de San Luis Potosí 2015. México: 39 y 48. Recuperado http://internet.contenidos.inegi.org.mx/contenidos/productos//prod_serv/contenidos /espanol/bvinegi/productos/nueva_estruc/inter_censal/panorama/702825082345.p df.

Joint United Nations Programme on HIVIADIS (2015). Global factsheets 2015. Recuperado de http://aidsinfo.unaids.org/ 
Diseño, implementación y evaluación de un programa de comunicación de riesgos como estrategia de prevención de la infección por VIH en adolescentes

Joint United Nations Programme on HIVIADIS (2016). Ending the AIDS epidemic for adolescents, with adolescents: A practical guide to meaningfully engage adolescents in the AIDS response. Recuperado de http://www.unaids.org/sites/default/files/media_asset/ending-AIDS-epidemicadolescents en.pdf. Recuperado el 29 de agosto de 2017

Kaur, M. (2016). Application of Mixed Method Approach in Public Health Research Indian. Journal of Community Medicine, 41(2), 93-98. doi: 10.4103/09700218.173495

Logie, C., Daniel, D. A., Newman, P., Weaver, J. y Loutfy, M. (2014). A PsychoEducational HIVISTI Prevention Intervention for Internally Displaced Women in Leogane, Haiti: Results from a Non-Randomized Cohort Pilot Study. PLoS ONE, 9(2). doi: 10.1371/journal.pone.0089836

March, J. (2011). El riesgo de una mala comunicación de riesgos. Revista de Comunicación y Salud, 1(2), 61-66.

Martínez-Garrido, C. y Murillo, J. (2016). Investigación iberoamericana sobre enseñanza eficaz. Revista Mexicana de Investigación Educativa, 21(69), 471-499.

Menna, T., Ali, A. y Worku, A. (2015). Effects of peer education intervention on HIVIAIDS related sexual behaviors of secondary school students in Addis Ababa Ethiopia: A quasi-experimental study. Reproductive Health, 12, 84. doi: 10.1186/s12978-

Meza-Lozano, B., Ortiz-Pérez M. D., Ponce-Palomares M. D., Castillo-Gutiérrez S. G., Flores-Ramírez R. y Cubillas-Tejeda A. C. (2016). Implementación y evaluación de un Programa de Comunicación de Riesgos por exposición a flúor en la comunidad de El Fuerte, Santa María del Río, San Luis Potosí, México. Revista Internacional de Contaminación Ambiental, 32(1), 87-100.

Moreno-Sánchez A. R., Cubillas-Tejeda A. C., Guerra-García A. y Peres F. (2016). Risk communication in Latin America. En Luiz Augusto Galvao, Jacobo Finkelman, and Samuel Henao (Ed.), Environmental and Social Determinants of Health (pp. 335360). Washington: Pan American Health Organization.

Moshki, M., Zamani-Alavijeh, F. y Mojadam, M. (2017). Efficacy of Peer Education for Adopting Preventive Behaviors against Head Lice Infestation in Female Elementary School Students: A Randomised Controlled Trial. PLOS ONE, 12(1). doi:10.1371/journal.pone.0169361.

Olave, I. y Villarreal, A. C. (2014). El proceso de corregulación del aprendizaje y la interacción entre pares. Revista Mexicana de Investigación Educativa, 19(61), 377399.

Organización Mundial de la Salud (2004). Una guía de indicadores para monitorear y evaluar los programas de prevención del VIH/sida para jóvenes. Recuperado de http://www.who.int/maternal_child_adolescent/documents/9241592575/es/.

Organización Mundial de la Salud (2016). Estrategia mundial del sector de la salud contra el VIH, 2016-2021. Recuperado de http://www.who.int/hiv/strategy20162021/ghss-hiv/es/.

Organización de las Naciones Unidas (2015). Objetivos de desarrollo sostenible. Recuperado de http://www.un.org/sustainabledevelopment/es/objetivos-dedesarrollo-sostenible/. 
Diseño, implementación y evaluación de un programa de comunicación de riesgos como estrategia de prevención de la infección por VIH en adolescentes

Pavía-Ruz, N., Góngora-Biachi, N., Vera-Gamboa, L., Moguel-Rodríguez, W. y González-Martínez, P. (2012). Conocimientos, actitudes y percepción de riesgo en referencia al VIH/SIDA en población rural de Yucatán, México. Revista Biomédica, 23(2), 53-60.

Quevedo-Gómez, M. C., Krumeich, A., Abadía-Barrero, C. E., Pastrana-Salcedo, E. M. y Van den Borne, H. (2011). Structural actions toward HIVIAIDS prevention in Cartagena, Colombia: a qualitative study. Revista Panamericana de Salud Pública, 30(1), 65-73.

Quintal López, R. y Vera Gamboa, L. (2015). Análisis de la vulnerabilidad social y de género en la díada Migración y VIH/SIDA entre mujeres mayas de Yucatán. Estudios de Cultura Maya, 197-226. Recuperado de http://www.scielo.org.mx/scielo.php?script=sci_arttext\&pid=S0185-

25742015000200197\&Ing=es\&tIng=es

Secretaría de Salud, Dirección General de Epidemiología y Centro Nacional para la Prevención y el Control del VIH y el sida (2016). Vigilancia Epidemiológica de VIH/SIDA en México, Registro Nacional de Casos de SIDA. Actualización al 15 de noviembre de 2016. Recuperado de http://www.censida.salud.gob.mx/descargas/epidemiologia/RN_DIA_MUNDIAL_20 16a.pdf.

Siddiqui, N. y Fitzgerald, J. A. (2014). Elaborated integration of qualitative and quantitative perspectives in mixed methods research: A profound enquiry into the nursing practice environment. International Journal of Multiple Research Approaches, 8(2), 137-147. doi: 10.1080/18340806.2014.11082056

Shilpa-Khanna, A., Dheeraj, S., Sanjay, C. y Piyush, G. (2015). Defining and measuring vulnerability in young people. Indian Journal Community Medicine, 40(3), 193-197. doi: 10.4103/0970-0218.158868

Silverman, David. (2016) [1997]. Qualitative Research. London: SAGE Publications, Ltd.

Slovic, P., Finucane, M., Peters, E. y MacGregor, D. (2004). Risk as Analysis and Risk as Feelings: Some Thoughts about Affect, Reason, Risk, and Rationality. Risk Analysis, 24(2), 311-322. doi: 10.1111/j.0272-4332.2004.00433.x

St. Lawrence, J., Seloilwe, E., Magowe, M., Dithole, K., Kgosikwena, B., Kokoro, E. y Lesaane, D. (2013). Cross-cultural adaptation of an adolescent HIV prevention program: Social validation of social contexts and behavior among Botswana adolescents. AIDS Education and Prevention, 25(4), 269-286. doi: 10.1521/aeap.2013.25.4.269

Suárez, N. (2014). Comunicación en estrategias de mercadeo social del condón masculino para la prevención del $\mathrm{VIH} /$ sida en Cuba. Revista de Comunicación y Salud, 4, 69-83.

Taylor, Steven J.; Bogdan, Robert y DeVault, Marjorie L. (2015) [1998]. Introduction to Qualitative Research Methods: A Guidebook and Resource. Hoboken, New Jersey: John Wiley \& Sons, Inc.

Tello, M. P. y Campos, M. E. (2015). Efectividad de un programa educativo sobre VIH/Sida aplicado a universitarios dentro del enfoque promocional. Cuidado $y$ Salud, 2(1), 125-136.

Terán-Hernández M., Díaz-Barriga F. y Cubillas-Tejeda A. C. (2016). "Diagnóstico de salud y percepción de riesgo, elementos clave para una propuesta de intervención 
Diseño, implementación y evaluación de un programa de comunicación de riesgos como estrategia de prevención de la infección por VIH en adolescentes

en comunidades indígenas en México". Revista Panamericana de Salud Pública, 39(2), 106-114.

Tosin, O. y Tshitangano, T. (2016). Assessment of learners'exposure to health education and promotion at school in the Limpopo Province of South Africa. African Journal Primary Health Care \& Family Medicine, 8(2).

United Nations Fund for Population Activities (2016). HIV-aids. Recuperado de: http://www.unfpa.org/es/vih-y-sida.

Vallejos-Romero, A. y Oñate-Ñancucheo, M. (2013). Comunicación de riesgos ecológicos: el caso de la contaminación atmosférica en dos ciudades intermedias del sur de Chile. Revista Internacional de Contaminación Ambiental, 29, 59-75.

Widman, L., Golin, C., Noar, S., Massey, J. y Prinstein, M. (2016). Projectheartforgirls.com: development of a web-based HIVISTD prevention program for adolescent girls emphasizing sexual communication skills. AIDS Education and Prevention, 28(5), 365-377. doi: 10.1521/aeap.2016.28.5.365

Zambrano, R., Castro, R., Lozano, M., Gómez, N. y Rojas, C. (2013). Conocimientos sobre VIH y comportamientos en Salud Sexual y Reproductiva en una comunidad indígena de Antioquía. Investigaciones Andina, 15(26), 640-652. 